\title{
Preparation of Derivatives of 3-Hydroxypicolinic
}

\section{Acid from Furfural}

\author{
NIELS CLAUSON-KAAS, JOHN BRAMMER PETERSEN, \\ GEORG OLE SøRENSEN, GERT OLSEN and GERT JANSEN
}

\author{
28 Rugmarken, Farum, Denmark
}

\begin{abstract}
Eight derivatives of 3-hydroxypicolinic acid have been prepared by oxidation of derivatives of $\alpha$-amino-2-furanacetic acid. These in turn were prepared from the corresponding 2-furaldehydes by Strecker-type reactions.
\end{abstract}

$\mathrm{O}_{\mathrm{t}}$ xidation of 2-( $\alpha$-aminoalkyl)furans gives good yields of 3-pyridinols under the proper reaction conditions. The method has been used for a number of laboratory preparations as well as for the industrial production of 3-pyridinol and of pyridoxine. The oxidation is usually carried out either electrolytically in methanol, or with chlorine or bromine in aqueous solution. ${ }^{1}$

An extension of the method to derivatives of $\alpha$-amino-2-furanacetic acid, all of which are available from furfural, resulted in the preparation of derivatives of 3-hydroxypicolinic acid (cf. Ref. 2). The reactions are shown on the next page. All oxidations were carried out with chlorine in aqueous solution.

\section{TRANSFORMATIONS OF FURFURAL INTO 3-HYDROXYPICOLINIC ACID DERIVATIVES}

The formation, by oxidation of furylhydantoin (VIII), of the pyridooxazine IX shows that an intramolecular nitrogen to oxygen acyl shift takes place during this oxidation. IX is easily hydrolyzed to 3 -hydroxypicolinamide (III).

The method was also tried successfully on two substituted furfurals, viz. the 3-methyl (XII) and the 4-isopropyl derivative (XVI). The reactions are shown below.

The substituted 3-hydroxypicolinonitriles XIV and XVIII may be hydrolyzed in high yields to the corresponding amides (XV and XIX, respectively) in strongly acidic solution. 


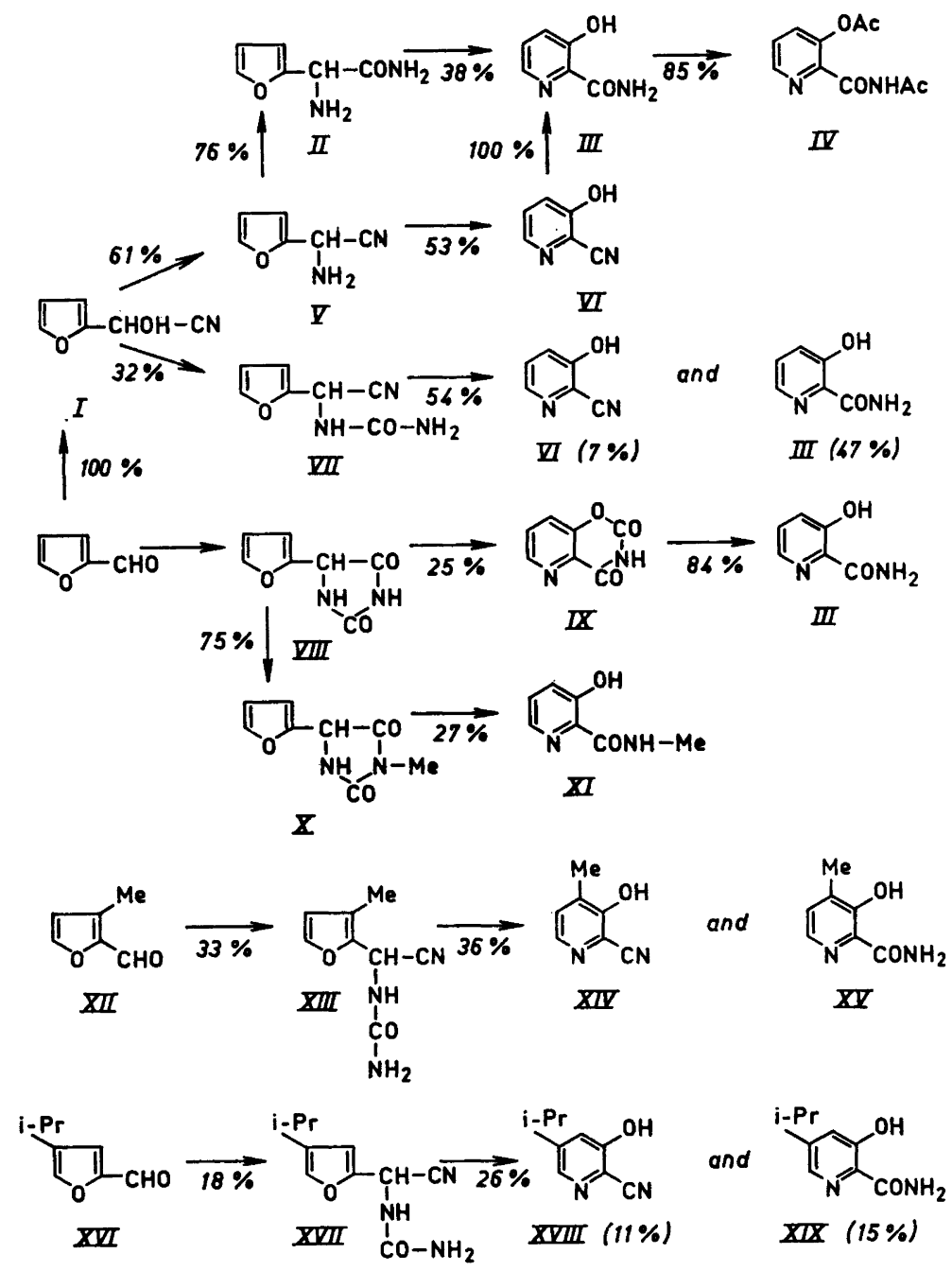

Compounds II, IV, VII, IX-XI, XIII-XV, and XVII-XIX are new. Their structures follow from the syntheses and from analyses. Those of the new compounds which are 3-pyridinols give, as expected, a red ferric chloride reaction.

\section{EXPERIMENTAL}

Crude 2-furanglycolonitrile (I) (cf. Refs. 3, 4). A mixture of furfural (38.4 g, 0.40 mole) and acetic acid $(26.4 \mathrm{~g}, 0.44 \mathrm{~mole})$ is added dropwise with stirring at $0^{\circ}$ to a solution of sodium cyanide $(21.5 \mathrm{~g}, 0.44 \mathrm{~mole})$ in water $(140 \mathrm{ml})$ during $30 \mathrm{~min}$. After about one third of the furfural-acetic acid mixture has been added, furanglycolonitrile begins to separate as an oil. After addition is complete, the oil is isolated by extraction with ether (three times), drying of the ethereal solution with magnesium sulfate, and removal of 
the ether by distillation from a water bath $\left(50^{\circ}\right)$, at last under $12 \mathrm{~mm}$. Crude furanglycolonitrile remains as an oil $(49.0 \mathrm{~g}, 100 \%)$.

$\alpha$-Amino-2-furanacetonitrile (V) hydrochloride (cf. Ref. 5). Crude furanglycolonitrile (I) (122 g, $0.99 \mathrm{~mole})$ is dissolved in $99 \%$ ethanol $(200 \mathrm{ml})$. Anhydrous magnesium sulfate $(100 \mathrm{~g})$ is added, the mixture cooled to $-35^{\circ}$ and liquid ammonia $(100 \mathrm{ml})$ added with stirring and cooling. After addition the mixture is removed from the cooling bath and stirred at room temperature. The temperature hereby rises from $-35^{\circ}$ to about $30^{\circ}$ during $1-1 \frac{1}{2} \mathrm{~h}$, then drops to room temperature $\left(22^{\circ}\right)$. The salt is removed by filtration and washed with ethanol $(100 \mathrm{ml})$. The clear, very dark solution (filtrate and washings) is distilled from a water bath $\left(50^{\circ}\right)$, at last under $20 \mathrm{~mm}$. The black oily residue is dissolved in ethanol $(200 \mathrm{ml})$ and ether $(200 \mathrm{ml})$. Freshly prepared $10 \mathrm{~N}$ ethanolic hydrogen chloride (about $35 \mathrm{ml}$ ) is added with stirring and cooling, until the amino group of the nitrile has been neutralized (controlled electrometrically with a glass electrode). The resulting light grey precipitate of the hydrochloride of $\mathrm{V}$ is isolated by filtration and washed with two $50 \mathrm{ml}$ portions of ether. The yield is $96 \mathrm{~g}(61 \%)$. The compound is somewhat hygroscopic and has no sharp melting point. [Found: $\mathrm{C}$ 45.4; $\mathrm{H} 4.7 ; \mathrm{N}$ 17.5; $\mathrm{Cl}$ 22.1. Cale. for $\mathrm{C}_{8} \mathrm{H}_{7} \mathrm{ClN}_{2} \mathrm{O}(158.6)$ : $\mathrm{C} \mathrm{45.5;} \mathrm{H} 4.5 ; \mathrm{N}$ 17.7; $\mathrm{Cl}$ 22.4].

$\alpha$-Amino-2-furanacetamide (II) hydrochloride. The hydrochloride of $\mathrm{V}(5.00 \mathrm{~g})$ is dissolved in water $(30 \mathrm{ml})$. Concentrated hydrochloric acid $(100 \mathrm{ml})$ is added at $20^{\circ}$ and the resulting suspension stirred overnight at $20^{\circ}$. Filtration and washing with $9 \mathrm{~N}$ hydrochloric acid $(25 \mathrm{ml})$ and ethanol $(25 \mathrm{ml})$ gives $4.24 \mathrm{~g}(76 \%)$ of the hydrochloride of II. The product is an almost white powder, melting in an evacuated tube at $275^{\circ}$ (Hershberg app., corr.) with destruction. [Found: $\mathrm{C} 40.7 ; \mathrm{H} 5.3 ; \mathrm{N} 16.0 ; \mathrm{Cl} 20.1$. Calc. for $\mathrm{C}_{6} \mathrm{H}_{9} \mathrm{ClN}_{2} \mathrm{O}_{2}$ (176.6): C 40.8; $\mathrm{H} 5.1 ; \mathrm{N} 15.9 ; \mathrm{Cl} 20.1]$.

3-Hydroxypicolinamide (III) from II. The hydrochloride of II $(1.77 \mathrm{~g}, 0.0100 \mathrm{~mole})$ was suspended in $6 \mathrm{~N}$ hydrochloric acid $(50 \mathrm{ml})$. Chlorine $(0.85 \mathrm{~g}, 0.0120$ mole) was passed into the suspension with stirring at $30^{\circ}$ during $90 \mathrm{~min}$. The clear, light yellow solution was brought to $\mathrm{pH} 2$ by addition of a $40 \%$ sodium hydroxide solution at $0^{\circ}$. The resulting precipitate was isolated by filtration, washing with water $(5 \mathrm{ml})$ and drying and purified by sublimation $\left(150^{\circ}, 0.1 \mathrm{~mm}\right)$, hereby yielding $0.53 \mathrm{~g}(38 \%)$ of III, m.p. $194^{\circ}$; previously found $194^{\circ}$ and $192-194^{\circ} .{ }^{\circ}$ The product gave a red ferric chloride reaction. [Found: $\mathrm{C} 51.5 ; \mathrm{H} 4.4 ; \mathrm{N} 20.3$. Calc. for $\mathrm{C}_{6} \mathrm{H}_{8} \mathrm{~N}_{2} \mathrm{O}_{2}(138.1)$ : $\mathrm{C} 52.2 ; \mathrm{H} \mathrm{4.4;} \mathrm{N} 20.3$ ].

Acetylation of 3-hydroxypicolinamide $(10.0 \mathrm{~g})$ with acetic anhydride-pyridine followed by crystallization from cyclohexane gave $13.7 \mathrm{~g}(85 \%)$ of $\mathrm{N}$-acetyl-3-acetoxypicolinamide (IV), m.p. 84 ${ }^{\circ}$. [Found: C 54.1; $\mathrm{H} 4.6 ; \mathrm{N} 12.6$; Ac 40.1. Calc. for $\mathrm{C}_{10} \mathrm{H}_{10} \mathrm{~N}_{2} \mathrm{O}_{4}$ (222.2): C 54.1; H 4.5; N 12.6; two Ac groups 38.7].

3-Hydroxypicolinonitrile (VI) from $V$. The hydrochloride of $\mathrm{V}(1.58 \mathrm{~g}, 0.0100 \mathrm{~mole})$ is suspended in $6 \mathrm{~N}$ hydrochloric acid $(40 \mathrm{ml})$. Chlorine $(0.85 \mathrm{~g}, 0.0120 \mathrm{~mole})$ is passed into the suspension with stirring at $30^{\circ}$ during $30 \mathrm{~min}$. The clear, light yellow solution is brought to $\mathrm{pH} 1$ by addition of a $40 \%$ sodium hydroxide solution at $0^{\circ}$. The resulting precipitate is isolated by filtration, washed with water $(5 \mathrm{ml})$ and dried $\left(70^{\circ}, 20 \mathrm{~mm}, 1 \mathrm{~h}\right)$, hereby yielding $0.63 \mathrm{~g} \mathrm{(53 \% )}$ of VI, m.p. in an evacuated tube $221^{\circ}$ (corr.); previously found ${ }^{8} 211-212^{\circ}$ (open tube, decomp., uncorr.). Sublimation $\left(150^{\circ}, 0.1 \mathrm{~mm}\right)$ gives $0.60 \mathrm{~g}$ of analytically pure product with the same melting point. The product gave a red ferric chloride reaction. [Found: $\mathrm{C} 59.8 ; \mathrm{H} \mathrm{3.5;} \mathrm{N} 23.7$. Calc. for $\mathrm{C}_{6} \mathrm{H}_{4} \mathrm{~N}_{2} \mathrm{O}(120.1)$ : $\mathrm{C}$ 60.0; H 3.4; N 23.3].

$\alpha$-Ureido-2-furanacetonitrile (VII). Crude furanglycolonitrile (I) $(24.5 \mathrm{~g})$ is mixed with urea $(48.0 \mathrm{~g}, 0.80 \mathrm{~mole})$ and heated rapidly with stirring to $100^{\circ}$. The reaction is somewhat exothermic and a certain amount of hydrogen cyanide is given off. Another $24.5 \mathrm{~g}$ of $\mathrm{I}$ is added at this temperature during $10 \mathrm{~min}, 49.0 \mathrm{~g}$ ( $(0.40 \mathrm{~mole})$ of $\mathrm{I}$ having thus been added in all. The resulting dark brown oil is crystallized from water $(300 \mathrm{ml})$ with several decantations from oily material, which sticks to the wall of the crystallization flask. The product is isolated by filtration, washed with water and dried at $\mathbf{8 0}^{\circ}$ (yield $28 \mathrm{~g}$ of a light brown powder, m.p. $147-149^{\circ}$ ). Crystallization from nitromethane $(60 \mathrm{ml})$ gives $21.0 \mathrm{~g}(32 \%)$ of VII, m.p. $152-154^{\circ}$. Another crystallization did not change the melting point. [Found: $\mathrm{C} 50.9 ; \mathrm{H} \mathrm{4.6} ; \mathrm{N}$ (Dumas) 23.2; $\mathrm{N}$ (Kjeldahl) 24.6. Calc. for $\mathrm{C}_{7} \mathrm{H}_{7} \mathrm{~N}_{3} \mathrm{O}_{2}$ (165.2): C $\left.50.9 ; \mathrm{H} 4.3 ; \mathrm{N} 25.5\right]$.

In our opinion the wrong values of the nitrogen analyses do not indicate that the substance is impure, but are caused by liberation of small amounts of cyanic acid in the Dumas as well as in the Kjeldahl determination.

Acta Chem. Scand. 19 (1965) No. 5 
Oxidation of $\alpha$-ureido-2-furanacetonitrile (VII). VII (16.5 g, 0.100 mole) was suspended in $6 \mathrm{~N}$ hydrochloric acid $(100 \mathrm{ml})$. Chlorine $(8.5 \mathrm{~g}, 0.12 \mathrm{~mole})$ was passed into the suspension with stirring at $0^{\circ}$ during $30 \mathrm{~min}$ (ether was added against foaming). The resulting dark green, clear solution was left standing at room temperature, whereby the temperature rose from $0^{\circ}$ to about $30^{\circ}$ during $20-30 \mathrm{~min}$. At the same time a lively evolution of carbon dioxide took place. The dark, strongly acidic solution was neutralized at $20^{\circ}$ with a $40 \%$ hydroxide solution (about $55 \mathrm{ml}$ ). The resulting precipitate was isolated by filtration, washed with water $(25 \mathrm{ml})$ and dried. $7.98 \mathrm{~g}$ of a light brown powder, m.. $190-210^{\circ}$ (decomp.) was hereby obtained.

Continuous extraction of the combined mother liquid and washings with ether overnight gave another $1.63 \mathrm{~g}$ of solid yellow material, m.p. $166-190^{\circ}$.

From the combined products $(9.61 \mathrm{~g})$ analytically pure 3 -hydroxypicolinamide (III) $(6.50 \mathrm{~g}, 47 \%)$ and analytically pure 3-hydroxypicolinonitrile (VI) $(0.89 \mathrm{~g}, 7 \%)$ were isolated by treatment with methanol and crystallization from nitromethane.

2H-Pyrido[2,3-e]-1,3-oxazine-2,4(3H)-dione (IX). 5-(2-Furyl)-hydantoin (VIII) monohydrate $^{9}(83 \mathrm{~g}, 0.45$ mole) is suspended in $3 \mathrm{~N}$ hydrochloric acid and chlorine (56 g, 0.79 mole) passed into the stirred suspension at $12-15^{\circ}$ during $2 \mathrm{~h}$. During addition of chlorine the precipitate of furylhydantoin gradually disappears, while, after about half of the chlorine has been added, the monohydrochloride of IX begins to precipitate. About 10 min after the addition of chlorine is completed the hydrochloride is isolated by

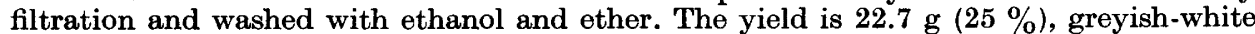
powder, m.p. 265-268 (decomp.). [Found: $\mathrm{C} 41.7 ; \mathrm{H} \mathrm{2.7}$; $\mathrm{N} 13.6$; $\mathrm{Cl} 17.2$. Calc. for $\mathrm{C}_{7} \mathrm{H}_{5} \mathrm{ClN}_{2} \mathrm{O}_{3}(200.5)$ : C 41.8; $\mathrm{H} \mathrm{2.5}$; $\mathrm{N} \mathrm{14.0;} \mathrm{Cl} \mathrm{17.7].}$

IX is so weak a base that it may be prepared from its hydrochloride by washing on a filter with water, until the filtrate is neutral. The wet product is then dried by washing with ethanol and ether. It is best crystallized from glacial acetic acid, m.p. $272-274^{\circ}$ (decomp.). [Found: $\mathrm{C} 51.0 ; \mathrm{H} \mathrm{2.5} ; \mathrm{N}$ 17.3. Calc. for $\mathrm{C}_{7} \mathrm{H}_{4} \mathrm{~N}_{2} \mathrm{O}_{3}$ (164.1): $\mathrm{C} 51.2 ; \mathrm{H} \mathrm{2.5}$; N 17.1].

3.Hydroxypicolinamide (III) from IX. The hydrochloride of IX (5.00 g, $0.025 \mathrm{~mole})$ is heated under reflux with water $(20 \mathrm{ml})$ for $30 \mathrm{~min}$. N Sodium hydroxide $(25.0 \mathrm{ml})$ is added dropwise with stirring to the hot solution. After cooling to room temperature the precipitate of III is isolated by filtration and the wet crystals crystallized from methanol. $2.89 \mathrm{~g}(84 \%)$ of III, m.p. $195-197^{\circ}$ is hereby obtained. (Found: C 52.4; $\mathrm{H}$ 4.4; $\mathrm{N} 20.5)$.

5-(2-Furyl)-2-methylhydantoin (X). Furylhydantoin monohydrate ${ }^{\circ}$ (36.8 g, 0.200 mole) is suspended in water $(200 \mathrm{ml})$. Methyl sulfate $(27.7 \mathrm{~g}, 0.220 \mathrm{~mole})$ is added dropwise with stirring during $30 \mathrm{~min}$ at $25-40^{\circ}$ and $\mathrm{pH} 9.0$ [automatic addition of a $40 \%$ sodium hydroxide solution, $16.0 \mathrm{ml}(0.23$ mole $)$ in all]. As the reaction proceeds, the precipitate of furylhydantoin is replaced by that of the methyl derivative. The suspension is brought to $\mathrm{pH} 7$ with about $4 \mathrm{ml}$ of $3 \mathrm{~N}$ hydrochloric acid and the precipitate isolated by filtration, washed with two $25 \mathrm{ml}$ portions of water and dried $\left(70^{\circ}, 10 \mathrm{~mm}, 1 \mathrm{~h}\right)$. The yield of crude $X$ is $27.0 \mathrm{~g}(75 \%)$, tan-colored crystals, m.p. $130-132^{\circ}$. A sample was crystallized from methanol to constant melting point $\left(134-135^{\circ}\right)$ and analysed. [Found: $\mathrm{C}$ 53.5; $\mathrm{H}$ 4.5; $\mathrm{N}$ 15.3. Calc. for $\mathrm{C}_{8} \mathrm{H}_{8} \mathrm{~N}_{2} \mathrm{O}_{3}(180.2)$ : $\mathrm{C} 53.3 ; \mathrm{H} 4.5 ; \mathrm{N} 15.6$ ].

N-Methyl-3-hydroxypicolinamide (XI). Crude furylmethylhydantoin $(\mathrm{X})(9.0 \mathrm{~g}$, $0.050 \mathrm{~mole})$ was suspended in $3 \mathrm{~N}$ hydrochloric acid $(50 \mathrm{ml})$. Chlorine $(5.0 \mathrm{~g}, 0.070 \mathrm{~mole})$ was passed into the suspension at $-5^{\circ}$ to $0^{\circ}$ during $20 \mathrm{~min}$. The resulting clear solution was left standing at $-5^{\circ}$ for $40 \mathrm{~min}$, during which time a fine yellow precipitate was formed. The precipitate (about $1 \mathrm{~g}$ ) was removed by filtration and the orange colored filtrate brought to $\mathrm{pH} 7.0$ at $-10^{\circ}$ with a $40 \%$ sodium hydroxide solution. There was much foaming (evolution of carbon dioxide) towards the end of the noutralization. A crystalline precipitate (leaves) was formed and removed by filtration from the dark red mother liquid. The reddish crystals were washed with two $5 \mathrm{ml}$ portions of water and dried $\left(30^{\circ}, 1 \mathrm{~mm}, 1 \mathrm{~h}\right)$. The yield was $2.00 \mathrm{~g}(27 \%)$ of XI, m.p. $62-64^{\circ}$, red ferric chloride reaction, characteristic odor. A portion was crystallized twice from water to give a sample melting at $64-65^{\circ}$. [Found: $\mathrm{C} 55.4 ; \mathrm{H}$ 5.2; $\mathrm{N}$ 18.2. Calc. for $\mathrm{C}_{7} \mathrm{H}_{8} \mathrm{~N}_{2} \mathrm{O}_{2}$ (152.2): C 55.3; H 5.3; N 18.4].

$\alpha$-Ureido-2-(3-methylfuran)acetonitrile (XIII). A mixture of 3-methylfurfural 10 (XII) $(6.09 \mathrm{~g}, 0.0554 \mathrm{~mole})$ and acetic acid (3.64 g, $0.0610 \mathrm{~mole})$ was added dropwise with stirring at $0^{\circ}$ to a solution of potassium cyanide $(4.02 \mathrm{~g}, 0.0610 \mathrm{~mole})$ in water 
$(15 \mathrm{ml})$ and ethanol $(18 \mathrm{ml})$ during $75 \mathrm{~min}$. The solution became tea-colored, but remained clear. The solution was kept at $10^{\circ}$ for $1 \mathrm{~h}$. Extraction with ether (3 portions), drying of the ethereal solution with magnesium sulfate, and evaporation of the solvents from a water bath $\left(60^{\circ}\right)$, at last under $20 \mathrm{~mm}$, gave $7.36 \mathrm{~g}$ of a clear brown oil, probably consisting mainly of the expected cyanohydrine. Urea $(4.86 \mathrm{~g}, 0.0810 \mathrm{~mole})$ and formic acid $(0.23 \mathrm{ml})$ were added to the oil, and the stirred mixture placed in a water bath $\left(100^{\circ}\right)$ for $20 \mathrm{~min}$. The resulting black paste was extracted with four $25 \mathrm{ml}$ portions of boiling water (decantation through a cake of celite). From the clear, aqueous extract yellow crystals separated on cooling. Filtration and crystallization of the wet cake of crystals from water $(100 \mathrm{ml})$ gave $3.22 \mathrm{~g}(33 \%$, based upon methylfurfural) of XIII, m.p. $145-147^{\circ}$. Another crystallization did not change the melting point. [Found: $C$ 53.8; $\mathrm{H}$ 5.2; $\mathrm{N}$ 23.5. Calc. for $\mathrm{C}_{8} \mathrm{H}_{9} \mathrm{~N}_{3} \mathrm{O}_{2}(179.1)$ : C 53.6; $\mathrm{H} 5.1 ; \mathrm{N} \mathrm{23.5] \text {. }}$

Oxidation of $\alpha$-ureido-2-(3-methylfuran)acetonitrile (XIII). A solution of chlorine $(2.02 \mathrm{~g}, 0.0284 \mathrm{~mole})$ in water $(325 \mathrm{ml})$ was added to a stirred suspension of XIII (3.22 $\mathrm{g}$, 0.0180 mole) in $6 \mathrm{~N}$ hydrochloric acid $(225 \mathrm{ml})$ at $0^{\circ}$ during $10 \mathrm{~min}$. A clear, light yellow solution resulted. The solution was left standing at $5^{\circ}$ for $30 \mathrm{~min}$ and was then heated to $85^{\circ}$ during $20 \mathrm{~min}$ and cooled rapidly. The clear, red reaction mixture was neutralized ( $\mathrm{pH}$ 6) with $40 \%$ sodium hydroxide. A precipitate was removed by filtration and dried $(0.38 \mathrm{~g})$. The filtrate was continuously extracted with ether overnight to give $0.76 \mathrm{~g}$ of crystalline material. The extracted material $(0.76 \mathrm{~g})$ was mixed with the material precipitated from the aqueous solution $(0.38 \mathrm{~g})$ and sublimated $\left(100^{\circ}, 0.05 \mathrm{~mm}\right)$, giving $0.96 \mathrm{~g}$ of light yellow crystals, which by thin layer chromatography were shown to consist of about equal parts of two compounds giving red ferric chloride reactions. Assuming the product to consist only of the expected nitrile (XIV) and the amide (XV), the yield corresponds to $36 \%$ of the theoretical amount.

The nitrile (XIV) was isolated pure by crystallization of part of the mixture $(0.60 \mathrm{~g})$ from boiling $0.8 \mathrm{~N}$ hydrochloric acid $(26 \mathrm{ml})$ and recrystallization from benzene $(3 \mathrm{ml})$. The yield of XIV was $0.12 \mathrm{~g}$, m.p. $176-177^{\circ}$ (decomp.). [Found: $\mathrm{C} 62.7 ; \mathrm{H} \mathrm{4.3;} \mathrm{N} \mathrm{20.4.}$ Calc. for $\mathrm{C}_{7} \mathrm{H}_{6} \mathrm{~N}_{2} \mathrm{O}(134.1)$ : C $\left.62.7 ; \mathrm{H} 4.5 ; \mathrm{N} 20.9\right]$.

The amide $(\mathrm{XV})$ was isolated pure by crystallization of the mixture from methanol, m.p. 188-190 $0^{\circ}$. [Found: $\mathrm{C} 55.6 ; \mathrm{H} 5.2 ; \mathrm{N} \mathrm{18.2.} \mathrm{Calc.} \mathrm{for} \mathrm{C}_{7} \mathrm{H}_{8} \mathrm{~N}_{2} \mathrm{O}_{2}(152.2)$ : C 55.3; $\mathrm{H}$ 5.3; N 18.4].

a-Ureido-2-(4-isopropylfuran)acetonitrile (XVII). The product was prepared from 4-isopropylfurfural ${ }^{11}$ (XVI) $(20.0 \mathrm{~g})$ after the directions given for the preparation of the corresponding 3-methyl derivative (XIII). The yield of XVII was $5.40 \mathrm{~g}(18 \%)$, m.p. $154-156^{\circ}$. [Found: $\mathrm{C} 58.0 ; \mathrm{H} \mathrm{6.4;} \mathrm{N} 20.3$. Calc. for $\mathrm{C}_{10} \mathrm{H}_{13} \mathrm{~N}_{3} \mathrm{O}_{2}(207.2)$ : C $58.0 ; \mathrm{H} 6.3$; N 20.3].

Oxidation of $\alpha$-ureido-2-(4-isopropylfuran)acetonitrile (XVII). XVII (5.40 g) was oxidized after the directions given for the oxidation of the corresponding 3-methyl derivative and the reaction products isolated in the same way. $1.16 \mathrm{~g}$ of white crystals (m.p. $137-160^{\circ}$ ) were hereby obtained. The product was by oxygen analysis (found: $O$ 14.1), infrared spectroscopy and thin layer chromatography shown to consist of the nitrile (XVIII) $(44 \%)$ and the amide (XIX) $(56 \%)$. The combined yield corresponds to $26 \%$, the yield of nitrile and amide being $11 \%$ and $15 \%$, respectively.

The nitrile (XVIII) was isolated pure by short heating of part of the mixture $(0.33 \mathrm{~g})$ with $2 \mathrm{~N}$ hydrochloric acid $(5 \mathrm{ml})$, whereby the amide dissolved. Cooling to $0^{\circ}$, filtration, washing with water and drying gave $0.12 \mathrm{~g}$ of XVIII, m.p. 185-190. Dissolution in acetone and precipitation with benzene gave a product with m.p. $189-190^{\circ}$. [Found:

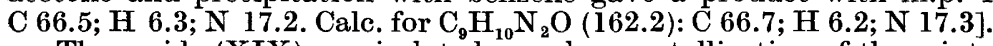

The amide (XIX) was isolated pure by crystallization of the mixture from methanol, m.p. 145-146 ${ }^{\circ}$. [Found: C 59.7; $\mathrm{H} 6.7 ; \mathrm{N}$ 15.5. Calc. for $\mathrm{C}_{9} \mathrm{H}_{12} \mathrm{~N}_{2} \mathrm{O}_{2}$ (180.2): C 60.0; $\mathrm{H} 6.7 ; \mathrm{N} 15.6]$.

Hydrolysis of nitriles to amides. The nitrile XIV $(0.095 \mathrm{~g})$ was dissolved in concentrated hydrochloric acid $(5 \mathrm{ml})$ and the solution left standing at room temperature for 5 days. Neutralization $\left(\mathrm{pH}^{5.5)}\right.$ and continuous extraction with ether gave $0.088 \mathrm{~g}(83 \%)$ of the corresponding amide (XV), m.p. $186-188^{\circ}$. Similarly the nitrile XVIII $(2.00 \mathrm{~g})$ and $150 \mathrm{ml}$ of concentrated hydrochloric acid gave $2.20 \mathrm{~g}(99 \%)$ of the amide XIX, m.p. $145-148^{\circ}$. 


\section{REFERENCES}

1. Elming, N. Advan. Org. Chem. 2 (1960) 67.

2. J. R. Geigy A. G. Fr. 1.338.291 (1963); Chem. Abstr. 60 (1964) 2955; Fr. 1.372 .758 (1964); Chem. Abstr. 62 (1965) 532.

3. Lukes, R., Kastner, F., Gut, J. and Herben, T. Collection Czech. Chem. Commun. 12 (1947) 647.

4. Nerdel, F., Kleeberg, W. and Schönewald, G. Chem. Ber. 87 (1954) 276.

5. Sugasawa, S. Yakugaku Zasshi 53 (1926) 64; Chem. Zentr. 1927:I 1463.

6. Bray, H. G., Neale, F. C. and Thorpe, W. V. Biochem. J. 46 (1950) 506.

7. Arnold, R. B., Johnson, A. W. and Mauger, A. B. J. Chem. Soc. 19584466.

8. Broekman, F. W., van Veldhuizen, A. and Janssen, H. Rec. Trav. Chim. 81 (1962) 792.

9. Fukumoto, T. and Murakami, M. Kogyo Kagaku Zasshi 66 (1963) 1310; Chem. Abstr. 60 (1964) 9351.

10. Reichstein, T., Zschokke, H. and Georg, A. Helv. Chim. Acta 14 (1931) 1277.

11. Elming, N. Acta Chem. Scand. 6 (1952) 605.

Received February 26, 1965. 